\title{
The prevalence of genital warts in the Baltic countries: findings from national cross-sectional surveys in Estonia, Latvia and Lithuania
}

\author{
Anneli Uusküla, ${ }^{1}$ Rainer Reile, ${ }^{1}$ Dace Rezeberga, ${ }^{2}$ Anda Karnite, ${ }^{3}$ Zeneta Logminiene, $^{4}$ \\ Žilvinas Padaiga, ${ }^{4}$ Mari Nygård $^{5}$
}

\begin{abstract}
- Additional supplementary material is published online only. To view please visit the journal online (http://dx.doi. org/10.1136/sextrans-2014051540)

${ }^{1}$ Department of Public Health, University of Tartu, Tartu, Estonia

${ }^{2}$ Department of Obstetrics and Gynecology, Riga Stradins University, Riga, Latvia ${ }^{3}$ Department of Public Health and Epidemiology, Riga Stradins University, Riga, Latvia ${ }^{4}$ Department of Preventive Medicine, Lithuanian University of Health Science, Kaunas, Lithuania

${ }^{5}$ Department of Research, Cancer Registry of Norway, Montebello, Oslo, Norway
\end{abstract}

\section{Correspondence to} Professor Anneli Uusküla, Department of Public Health, University of Tartu, Ravila str 19, Tartu 50411, Estonia; anneli.uuskula@ut.ee

Received 24 January 2014 Revised 6 June 2014 Accepted 19 July 2014 Published Online First 7 August 2014
CrossMark

To cite: Uusküla A, Reile $R_{\text {, }}$ Rezeberga $D$, et al. Sex Transm Infect 2015;91: 55-60.

\section{ABSTRACT}

Objectives To assess the prevalence and correlates of self-reported genital warts (GWs) among women and men aged 18-45 years in the Baltic countries.

Methods In 2011-2013 we performed a crosssectional survey using a self-administered questionnaire to collect information on the history of clinically diagnosed GWs, sociodemographic characteristics and sexual behaviour. Probability sampling methods were used to invite 16959 individuals representing the general population, of whom 7760 (45.8\%) participated (Estonia: 1967 women, 1221 men; Latvia: 1525 women, 1525 men; Lithuania: 1522 women).

Results The estimated lifetime prevalence of clinically diagnosed GWs in women was $4.6 \%(95 \% \mathrm{Cl} 3.8$ to $5.5)$ in Estonia, $2.9 \%(95 \% \mathrm{Cl} 2.0$ to 3.6$)$ in Latvia and $1.5 \%(95 \% \mathrm{Cl} 1.2$ to 2.0$)$ in Lithuania. Among men, the corresponding values were $2.8 \%(95 \% \mathrm{Cl} 1.9$ to 4.0) in Estonia and $1.9 \%(95 \% \mathrm{Cl} 1.3$ to 2.6$)$ in Latvia. The mean age at first episode of clinically diagnosed GW was 24.6 years $(95 \% \mathrm{Cl} 23.6$ to 25.5$)$ for women and 24.5 years $(95 \% \mathrm{Cl} 22.9$ to 26.0$)$ for men. A lifetime history of clinically diagnosed GW was associated with a history of sexually transmitted infections other than GW (adjusted OR (AOR) 3.0, 95\% Cl 2.1 to 4.3 for women; AOR $5.3,95 \% \mathrm{Cl} 3.0$ to 9.2 for men), and a higher number $(5+)$ of lifetime sexual partners (AOR 2.9, 95\% $\mathrm{Cl} 1.9$ to 4.2 for women; AOR $2.1,95 \% \mathrm{Cl} 1.2$ to 3.9 for men). Men living comfortably within their household income had higher odds for GW (AOR 1.9, 95\% Cl 1.1 to 3.2).

Conclusions Our estimated prevalence of clinically diagnosed GWs was lower than estimates from the general population of other European countries.

\section{INTRODUCTION}

Although genital warts (GWs) rank among the most frequent sexually transmitted infections (STIs) their epidemiology is not well characterised. ${ }^{1}$ Human papillomavirus (HPV) types 6 and 11 cause more than $90 \%$ of GWs. ${ }^{2}$ The quadrivalent HPV vaccine provides protection against both these types, and the cancer-causing types 16 and $18 .^{3} \mathrm{At}$ the population level, GW is one of the earliest possible disease outcomes that can be measured to assess the effectiveness of HPV vaccination programmes. ${ }^{4} 5$ Thus, regional data on the prevalence of GWs increase the understanding of the epidemiology of HPV infection, aid in the planning of reproductive health programmes, and make an important contribution to programme effectiveness, analysis and decision making. Knowledge of the overall prevalence of GW by geographical region and sex, as well as changes in this prevalence across different birth cohorts, are important research areas.

A recent paper by Patel et $a l^{1}$ reviewed nine studies of GW prevalence conducted since 1998 in the general populations of Argentina, Brazil, Australia, China, Denmark, Iceland, Norway, Sweden, England, Scotland, Wales, Slovenia and the USA. The lifetime prevalence estimates, based on self-reported, clinically diagnosed GW varied from $0.36 \%$ (Slovenia) to $12.0 \%$ (Iceland) among women, and from $0.27 \%$ (Slovenia) to $7.9 \%$ (Denmark) among men. ${ }^{1}$ In addition, in these studies more women than men admitted to having a history of GW. ${ }^{1}$

To our knowledge, data on the occurrence of HPV-related genital disease from Central and Eastern European countries is scant. Here, we report a study assessing the prevalence of selfreported clinically diagnosed GW and related factors among 18-45-year-old women and men in Estonia, Latvia and Lithuania before the introduction of mass vaccination programmes.

\section{METHODS}

\section{Sampling and study population}

In 2011-2013, population-based, cross-sectional studies were conducted among women and men aged 18-45 years from the general populations of Estonia, Latvia, and Lithuania. The calculated sample size needed (assuming 1\% prevalence of clinically diagnosed GW, desired precision $0.5 \%$ ) was 1522 (for men and women).

In order to obtain representative samples of the general population, sampling methodologies were based on the feasibility and previous experiences of the researchers in the respective countries. ${ }^{6-9}$ In Estonia, the National Population Registry was used to obtain a random sample of 3804 women aged 18-45 years and 3806 men aged 18-45 years (the sample size accounting for response rates reported for mailed surveys). ${ }^{8} 10$

In Latvia and Lithuania, multistage stratified probability sampling was used.

In both countries, the primary sampling units (PSUs) were geographical regions selected with probability proportional to size from a list stratified by administrative-territorial region, settlement type 
(capital, other cities, rural localities) and (in Latvia only) gender. This produced a sample of 221 PSUs in Latvia and 160 in Lithuania. Addresses from the Population Registry of the Latvian Office of Citizenship and Migration Affairs and the Lithuanian State Enterprise Centre of Registers, respectively, served as sampling frames.

Not more than 10 study subjects were recruited from each PSU in Latvia and Lithuania. For recruitment, beginning at randomly selected starting points (ie, addresses), field workers went from door to door along a street by increasing house number, stopping at every second house on one side of the street. During this process field workers identified and accessed housing units containing potentially eligible men and women aged 18-45 years: 3129 and 3479, respectively in Latvia; and 2741 (women only) in Lithuania. One eligible person per housing unit was invited to the study using the first birthday rule (selecting of interviewee by the method of first coming birthday closest to the day of survey).

Study participation was anonymous in Latvia and Lithuania, and confidential in Estonia. The study subjects did not receive any financial incentive for participation.

\section{Data collection}

Information about symptoms that might have been warts and on clinically diagnosed GW (ie, GW diagnosed by a healthcare provider) and selected socioeconomic, sexual and health behaviour characteristics (smoking history, hormonal contraceptive use, sexual health-related healthcare visits, and history of STIs other than GW) were collected using a structured self-administered questionnaire, which required about $20 \mathrm{~min}$ to complete. ${ }^{11} 12$ In Estonia, the study questionnaire, a personalised invitation and a prestamped, preaddressed envelope for return of the questionnaire were mailed to potential study participants. After 2 weeks, a reminder was sent to non-responders, and after 4 weeks the full package of study materials was sent again to those who had not yet responded (reminder and second mailing of study materials was executed based on the study-specific identification code and unlinked from the data collected from the returned questionnaires). ${ }^{7}{ }^{8}$ In Latvia and Lithuania, field workers delivered study questionnaires and sealable envelopes; sealed envelopes with completed questionnaires were collected by the field workers at a time agreed with the participant (no personally identifiable information was captured).

The study questionnaire was developed in English and then translated into the local languages. In Estonia and Latvia all study documents (invitations, questionnaires, informed consent forms) were prepared in two languages (Estonian or Latvian; and Russian). In Lithuania the study materials were produced in Lithuanian only. The adaptation process consisted of several steps including translation, panels of bilingual people agreeing a 'best fit' for the translated questionnaires, and field testing of the resultant questionnaire (piloting) as suggested by Bhopal et $a l .{ }^{13}$ As this study required translation into more than one language, each language version was compared with the others to ensure comparability. In Estonia, the language of the mailed questionnaire was based on the mother tongue information available in the Population registry, and in Latvia on the discretion of the contacted respondent.

\section{Statistical analysis}

Response rates were calculated following the guidelines from The American Association for Public Opinion Research ${ }^{14}$ and response rates presented were derived by dividing the number of individuals who submitted the self-administered questionnaire by the total number of individuals invited.

Descriptive statistics were used (including mean, proportions and range for continuous variables; percentages and absolute frequencies for categorical variables) to summarise the data by country and age group ( $\leq 24$ years, $25-34$ years, $35+$ years). The $\chi^{2}$ test for categorical variables was used to explore differences between groups, and the Mann-Whitney and Kruskal-Wallis tests were used for non-normally distributed continuous variables, as appropriate.

For prevalence estimates, the proportion of participants selfreporting clinically diagnosed GW (time frame: lifetime or last 12 months) was calculated. GW prevalence estimates were weighted to account for non-response. The data were weighted to be representative of the reference populations (according to 2011 censuses in Estonia, Latvia and Lithuania) by age (separately for men and women). Crude and weighted GW prevalences are presented together with 95\% CIs.

Associations of history of GW were examined using univariate and multivariable logistic regressions, from which ORs and adjusted ORs (AORs), with corresponding 95\% CIs, were estimated. Multivariable analysis was performed separately for men and women. Factors significantly associated with the outcome at an $\alpha$ level of 0.05 were included in multivariable models. The multivariable analysis was initially performed separately for each country; however, because the results were very similar (data not shown), we included all three countries in one analysis, adjusting for country in the final statistical model. In the multivariable logistic regression, unweighted regression estimates were used. ${ }^{15}$

\section{RESULTS}

Altogether, data on 7760 participants were collected: 3188 from Estonia (1967 women, 1221 men), 3050 from Latvia (1525 women, 1525 men) and 1522 from Lithuania (women only). Survey response rate was $45.8 \%$ overall: $42 \%$ in Estonia (52\% for women, $32 \%$ for men), $46 \%$ in Latvia (49\% for women, 44\% for men) and 56\% in Lithuania (women only).

Nearly $25 \%$ of the study participants were 24 years old or younger, 61\% were married or cohabiting (men were less likely to be married or cohabiting than women, $\mathrm{p}<0.001$ ), and $40 \%$ had up to 12 years of education (men were less likely to have $\geq 13$ years of education than women, $p<0.001$ ).

The median lifetime number of sexual partners was three for women (SD 7.0) and five for men (SD 41.8) (women vs men $\mathrm{p}<0.001$ ); and the median age at first sexual intercourse was 18 years (SD 2.4; range 12-31 years) for women and 17 years (SD 2.6; range 7-43 years) for men (women vs men $\mathrm{p}<0.001$ ). Seventeen per cent of women and $10 \%$ of men reported ever having STIs other than GW (table 1).

Across the three countries, 154 women (89, 43 and 22 in Estonia, Latvia and Lithuania, respectively) and 65 men (35 and 30 in Estonia and Latvia, respectively) reported a history of clinically diagnosed GW, which translates into a (weighted) prevalence of $2.7 \%$ (95\% CI $2.4 \%$ to $3.0 \%$ ) of $18-45$-year-olds in the Baltic countries (table 1).

For women, the estimated lifetime prevalence of selfreported, clinically diagnosed GW ranged from 4.6\% $95 \% \mathrm{CI}$ $3.8 \%$ to $5.5 \%$ ) in Estonia to $1.5 \%$ (95\% CI $1.2 \%$ to $2.0 \%$ ) in Lithuania. For men, the point estimate of lifetime prevalence of self-reported, clinically diagnosed GW was slightly higher in Estonia $(2.8 \%, 95 \%$ CI $1.9 \%$ to $4.0 \%)$ than in Latvia $(1.9 \%$, $95 \%$ CI $1.3 \%$ to $2.6 \%)(p=0.12)$ (table 1$)$ (online supplementary figure 1 presents age group and gender-specific estimates). 
Table 1 Sociodemographic, sexual and healthcare behaviour characteristics, and the prevalence of self-reported, clinically diagnosed genital warts among women and men aged 18-45 years in the Baltic countries in 2011-2013

\begin{tabular}{|c|c|c|c|c|c|c|c|c|c|}
\hline & \multicolumn{4}{|c|}{ All $(\mathrm{N}=7760)$} & \multicolumn{2}{|l|}{ Estonia $(n=3188)$} & \multicolumn{2}{|l|}{ Latvia $(n=3050)$} & \multirow{3}{*}{$\begin{array}{l}\text { Lithuania } \\
(n=1522) \\
\text { Women } \\
(n=1522) \\
\text { Per cent }\end{array}$} \\
\hline & \multicolumn{2}{|c|}{ Men $(n=2746)$} & \multicolumn{2}{|c|}{ Women $(n=5014)$} & \multirow{2}{*}{$\begin{array}{l}\text { Men }(n=1221) \\
\text { Per cent }\end{array}$} & \multirow{2}{*}{$\begin{array}{l}\text { Women } \\
(n=1967) \\
\text { Per cent }\end{array}$} & \multirow{2}{*}{$\begin{array}{l}\text { Men } \\
(n=1525) \\
\text { Per cent }\end{array}$} & \multirow{2}{*}{$\begin{array}{l}\text { Women } \\
(n=1525) \\
\text { Per cent }\end{array}$} & \\
\hline & n & Per cent & $\mathrm{n}$ & Per cent & & & & & \\
\hline \multicolumn{10}{|l|}{ Age (years) } \\
\hline $18-19$ & 181 & 7 & 262 & 5 & 4 & 2 & 11 & 9 & 5 \\
\hline $20-24$ & 579 & 21 & 906 & 18 & 20 & 16 & 26 & 18 & 20 \\
\hline $25-29$ & 479 & 17 & 850 & 17 & 16 & 16 & 16 & 16 & 16 \\
\hline $30-34$ & 421 & 15 & 846 & 17 & 14 & 18 & 14 & 16 & 17 \\
\hline $35-39$ & 438 & 16 & 854 & 17 & 19 & 20 & 11 & 13 & 15 \\
\hline $40+$ & 648 & 24 & 1296 & 26 & 27 & 27 & 22 & 29 & 27 \\
\hline Married or cohabiting & 1517 & 55 & 3206 & 64 & 65 & 74 & 44 & 56 & 59 \\
\hline Ethnicity (main*) & 1889 & 69 & 3831 & 76 & 77 & 76 & 63 & 65 & 88 \\
\hline Employed & 1855 & 68 & 3152 & 63 & 73 & 65 & 60 & 60 & 64 \\
\hline $\begin{array}{l}\text { Coping with household } \\
\text { income: difficult or } \\
\text { very difficult }\end{array}$ & 1208 & 45 & 2336 & 47 & 36 & 38 & 51 & 58 & 49 \\
\hline Ever smoked & 1881 & 69 & 2315 & 46 & 67 & 48 & 69 & 47 & 45 \\
\hline $\begin{array}{l}\text { Age at first sexual } \\
\text { intercourse } \leq 15 \text { years }\end{array}$ & 456 & 18 & 487 & 10 & 18 & 13 & 20 & 9 & 7 \\
\hline $\begin{array}{l}\text { Lifetime number of } \\
\text { sexual partners } \geq 5\end{array}$ & 1281 & 53 & 1480 & 33 & 55 & 44 & 51 & 30 & 20 \\
\hline $\begin{array}{l}\text { History of STI other } \\
\text { than genital warts } \\
\text { (yes) } \dagger\end{array}$ & 269 & 10 & 856 & 17 & 13 & 29 & 7 & 12 & 7 \\
\hline $\begin{array}{l}\text { Reproductive/genital } \\
\text { healthcare visit (ever) }\end{array}$ & 1152 & 42 & 4510 & 90 & 44 & 90 & 39 & 92 & 90 \\
\hline $\begin{array}{l}\text { Hormonal } \\
\text { contraceptive use } \\
\text { (ever) }\end{array}$ & NA & NA & 1205 & 43 & NA & 73 & NA & 55 & 51 \\
\hline \multicolumn{10}{|c|}{ Ever thought they had a lump or a bump that might have been a genital wart, $n, \%(95 \% \mathrm{Cl})$} \\
\hline Crude prevalence & 166 & $6.0(5.2$ to 7.0$)$ & 353 & 7.0 (6.4 to 7.8$)$ & 8.0 (6.6 to 9.7$)$ & 10.1 (8.9 to 11.5$)$ & 4.5 (3.5 to 5.6$)$ & $5.2(4.2$ to 6.5$)$ & 4.9 (3.9 to 6.1$)$ \\
\hline Weighted prevalence & 149 & 5.8 (4.9 to 6.7$)$ & 497 & 6.8 (6.3 to 7.4$)$ & 8.1 (6.5 to 10.0$)$ & 10.2 (9.1 to 11.4$)$ & 4.4 (3.5 to 5.5$)$ & $5.2(4.2$ to 6.4$)$ & 4.9 (4.2 to 5.7$)$ \\
\hline \multicolumn{10}{|c|}{ Self-reported history of clinically diagnosed genital warts during lifetime, n, \% (95\% Cl) } \\
\hline Crude prevalence & 65 & $2.4(1.9$ to 3.0$)$ & 154 & 3.1 (2.6 to 3.6$)$ & $2.9(2.1$ to 4.0$)$ & 4.5 (3.7 to 5.5$)$ & $2.0(1.4$ to 2.8$)$ & $2.8(2.1$ to 3.8$)$ & $1.4(0.9$ to 2.2$)$ \\
\hline Weighted prevalence & 57 & $2.2(1.7$ to 2.9$)$ & 208 & $2.9(2.5$ to 3.3$)$ & $2.8(1.9$ to 4.0$)$ & $4.6(3.8$ to 5.5$)$ & $1.9(1.3$ to 2.6$)$ & $2.9(2.0$ to 3.6$)$ & $1.5(1.2$ to 2.0$)$ \\
\hline \multicolumn{10}{|c|}{ Self-reported history of clinically diagnosed genital warts during the last 12 months, $n, \%(95 \% \mathrm{Cl})$} \\
\hline Crude prevalence & 14 & $0.5(0.3$ to 0.9$)$ & 30 & $0.6(0.4$ to 0.9$)$ & 0.7 (0.3 to 0.9$)$ & 0.8 (0.5 to 1.3$)$ & $0.4(0.2$ to 0.9$)$ & 0.6 (0.3 to 1.1$)$ & $0.4(0.2$ to 0.9$)$ \\
\hline Weighted prevalence & 12 & $0.5(0.3$ to 0.8$)$ & 41 & $0.6(0.4$ to 0.8$)$ & $0.6(0.3$ to 1.3$)$ & $0.8(0.5$ to 1.2$)$ & $0.4(0.2$ to 0.8$)$ & $0.6(0.3$ to 1.1$)$ & $0.4(0.2$ to 0.7$)$ \\
\hline
\end{tabular}

*Main ethnic group: Estonians, Latvians, Lithuanians.

†STI, sexually transmitted infection; includes genital chlamydial infection, gonorrhoea, trichomoniasis, herpes and/or syphilis ever diagnosed by a physician (does not include HIV infection).

The mean age at first episode of clinically diagnosed GW was 24.6 years (95\% CI 23.6 to 25.5 ) for women and 24.5 years (95\% CI 22.9 to 26.0 ) for men, with no statistically significant differences observed between countries or sexes.

Of the entire study sample, $0.5 \%$ (95\% CI $0.4 \%$ to $0.7 \%)$ of participants ( $n=44 ; 30$ women, 14 men) reported a diagnosis of GW within the last 12 months (women: $0.6 \% 95 \%$ CI $0.4 \%$ to $0.8 \%$; men: $0.5 \% 95 \%$ CI $0.3 \%$ to $0.8 \%$ ) (table 1 ).

Diagnoses of GW during the past 12 months were most frequently reported in the 30-34 years age group for women $(1.2 \%$, $95 \%$ CI $0.7 \%$ to $1.9 \%)$, and men $(0.8 \%, 95 \%$ CI $0.3 \%$ to $2.5 \%)$.

Having had sex with a partner of the same gender was reported by $2.6 \%$ of men and $3.1 \%$ of women. The difference in prevalence of GW (self-report, lifetime) among men reporting sex with men (MSM) in comparison with those exclusively having female partner(s) (non-MSM) was close to statistical significance (MSM vs non-MSM, 6.7\% vs $2.4 \%, \mathrm{p}=0.063$ ) (of note, only a small fraction (7\%) of GW (self-report, lifetime) reported by men were reported by MSM).

Table 2 displays factors associated with a lifetime history of GW. We found that the most important correlate associated with a history of GW for both sexes was a history of STIs other than GW (AOR for women: 3.0, 95\% CI 2.1 to 4.3; for men: 5.3, 95\% CI 3.0 to 9.2). Lifetime number of sexual partners was also associated with higher odds for history of GW $(5+$ partners: women: AOR 2.9, 95\% CI 1.9 to 4.2 ; men: AOR 2.1, $95 \%$ CI 1.2 to 3.9 ). Men coping or living comfortably within their household income (AOR 1.9, 95\% CI 1.1 to 3.2) had higher odds for GW (table 2).

In a separate analysis, we analysed the possible effect of hormonal contraceptive use on history of clinically diagnosed GW. In our data, previous hormonal contraceptive use was not 
Table 2 The prevalence of and factors associated with reporting ever receiving a clinical diagnosis of genital warts for women and men aged 18-45 years in the Baltic countries in 2011-2013

\begin{tabular}{|c|c|c|c|c|c|c|}
\hline & \multicolumn{3}{|l|}{ Men } & \multicolumn{3}{|l|}{ Women } \\
\hline & $\%(95 \% \mathrm{Cl})$ & OR $(95 \% \mathrm{Cl})$ & $\mathrm{AOR}^{*}(95 \% \mathrm{Cl})$ & $\%(95 \% \mathrm{Cl})$ & OR $(95 \% \mathrm{Cl})$ & AORt $(95 \% \mathrm{Cl})$ \\
\hline \multicolumn{7}{|l|}{ Country } \\
\hline Estonia & $2.9(2.1$ to 4.0$)$ & 1 & 1 & 4.5 (3.7 to 5.5$)$ & 3.1 (2.2 to 4.3$)$ & 1.6 (1.0 to 2.6$)$ \\
\hline Latvia & 2.0 (1.4 to 2.8$)$ & $0.6(0.4$ to 1.1$)$ & $0.9(0.5$ to 1.5$)$ & 2.8 (2.1 to 3.8$)$ & 1.8 (1.2 to 2.7$)$ & $1.4(0.8$ to 2.4$)$ \\
\hline Lithuania & na & na & na & 1.5 (1.0 to 2.2$)$ & 1 & 1 \\
\hline \multicolumn{7}{|l|}{ Age (years) } \\
\hline$\leq 24$ & $0.9(0.5$ to 1.9$)$ & 0.2 (0.1 to 0.6$)$ & $0.6(0.3$ to 1.6$)$ & $1.5(0.9$ to 2.3$)$ & $0.4(0.2$ to 0.6$)$ & $0.7(0.4$ to 1.3$)$ \\
\hline $25-34$ & 3.0 (2.1 to 4.3$)$ & $1(0.6$ to 1.8$)$ & $1.2(0.7$ to 2.2$)$ & 4.1 (3.2 to 5.1$)$ & $1.3(1.0$ to 1.7$)$ & $1.3(0.9$ to 1.9$)$ \\
\hline $35+$ & $2.9(2.0$ to 4.0$)$ & 1 & 1 & $3.2(2.5$ to 4.0$)$ & 1 & 1 \\
\hline \multicolumn{7}{|l|}{ Education } \\
\hline$\leq 12$ years & 2.0 (1.4 to 2.9$)$ & 0.7 (0.4 to 1.2$)$ & na & 2.9 (2.2 to 3.8$)$ & 1 (0.8 to 1.4$)$ & na \\
\hline $13+$ years & $2.8(2.0$ to 3.9$)$ & 1 & na & $3.1(2.6$ to 3.8$)$ & 1 & na \\
\hline \multicolumn{7}{|l|}{ Marital status } \\
\hline Married or cohabiting & 2.8 (2.1 to 3.8$)$ & 1.9 (1.1 to 3.3$)$ & $0.9(0.5$ to 1.6$)$ & 3.2 (2.7 to 3.9$)$ & $1.2(0.9$ to 1.6$)$ & na \\
\hline Other & 1.8 (1.2 to 2.7$)$ & 1 & 1 & $2.8(2.1$ to 3.6$)$ & 1 & na \\
\hline \multicolumn{7}{|l|}{ Ethnicity } \\
\hline Main & 2.5 (1.9 to 3.4$)$ & 1.3 (0.7 to 2.4$)$ & na & $3.0(2.5$ to 3.6$)$ & $0.9(0.6$ to 1.2$)$ & na \\
\hline Other & 2.0 (1.3 to 3.2$)$ & 1 & na & 3.3 (2.4 to 4.5 ) & 1 & na \\
\hline \multicolumn{7}{|l|}{ Employment } \\
\hline Employed & 2.6 (2.0 to 3.5$)$ & 1.7 (0.9 to 3.1$)$ & na & 3.3 (2.8 to 4.0$)$ & $1.3(0.9$ to 1.7$)$ & na \\
\hline Other & 1.7 (1.0 to 2.8$)$ & 1 & na & 2.6 (2.0 to 3.4$)$ & 1 & na \\
\hline \multicolumn{7}{|l|}{ Coping with household income } \\
\hline Living comfortably or coping & 2.9 (2.2 to 3.9$)$ & 1.8 (1.0 to 3.2$)$ & $1.9(1.1$ to 3.2$)$ & $3.9(3.2$ to 4.8$)$ & $1.2(0.9$ to 1.6$)$ & na \\
\hline Difficult or very difficult & 1.7 (1.1 to 2.5$)$ & 1 & 1 & 2.7 (2.2 to 3.5$)$ & 1 & na \\
\hline \multicolumn{7}{|l|}{ Smoking } \\
\hline Ever & 2.6 (2.0 to 3.4$)$ & 1.5 (0.8 to 2.7 ) & na & 3.9 (3.2 to 4.8$)$ & 1.8 (1.4 to 2.4$)$ & 1.1 (0.8 to 1.7$)$ \\
\hline Never & 1.8 (1.1 to 2.9$)$ & 1 & na & 2.4 (1.8 to 3.0$)$ & 1 & 1 \\
\hline \multicolumn{7}{|l|}{ Age at first sexual intercourse } \\
\hline$\leq 15$ years & 3.1 (1.8 to 5.1$)$ & $1.3(0.7$ to 2.4$)$ & na & 5.5 (3.8 to 8.0$)$ & $1.9(1.3$ to 2.8$)$ & $1.2(0.8$ to 1.9$)$ \\
\hline $16+$ years & 2.5 (1.9 to 3.2$)$ & 1 & na & $3.0(2.5$ to 3.5$)$ & 1 & 1 \\
\hline \multicolumn{7}{|l|}{ Lifetime number of sexual partners } \\
\hline 5 or more & $3.8(2.9$ to 5.0$)$ & $3.0(1.6$ to 5.6$)$ & $2.1(1.2$ to 3.9$)$ & $6.6(5.5$ to 8.0$)$ & 4.5 (3.3 to 6$)$ & 2.9 (1.9 to 4.2$)$ \\
\hline $0-4$ & 1.3 (0.8 to 2.2$)$ & 1 & 1 & 1.6 (1.2 to 2.1$)$ & 1 & 1 \\
\hline \multicolumn{7}{|c|}{ History of STI other than genital wartsł } \\
\hline Yes & $9.3(6.4$ to 13.4$)$ & $7.4(4.3$ to 12.9$)$ & 5.3 (3.0 to 9.2 ) & 8.8 (7.1 to 10.8$)$ & $5.3(4.0$ to 7.1$)$ & $3.0(2.1$ to 4.3$)$ \\
\hline No & $1.6(1.2$ to 2.2$)$ & 1 & 1 & $1.9(1.5$ to 2.4$)$ & 1 & 1 \\
\hline
\end{tabular}

associated with a history of GW (AOR 1.1 (vs never), 95\% CI 0.8 to 1.6$)$ (data not shown).

\section{DISCUSSION}

In this population-based study of nearly 7800 women and men aged 18-45 years, we found that the lifetime prevalence of selfreported, clinically diagnosed GW ranged among women from $4.6 \%$ (95\% CI $3.7 \%$ to $5.5 \%$ ) in Estonia to $2.9 \%(95 \%$ CI $2.1 \%$ to $3.8 \%)$ in Latvia and $1.5 \%$ (95\% CI $0.9 \%$ to $2.2 \%$ ) in Lithuania; and for men from $2.8 \%$ (95\% CI $1.9 \%$ to $4.0 \%$ ) in Estonia to $1.9 \%$ (95\% CI $1.3 \%$ to $2.6 \%$ ) in Latvia.

The self-reported prevalence of clinically diagnosed GW differed across the three Baltic countries. Yet, the reported prevalences were lower than those reported from Nordic countries (10\% among women aged $18-45$ years), ${ }^{11}$ the UK (among sexually experienced $18-44$ year-old women $4.1 \%$ and men
$3.6 \%),{ }^{16}$ Denmark $(7.9 \% \text { men aged } 18-45 \text { years })^{17}$ or the USA (7.2\% among women, $4 \%$ among men aged $18-59$ years). ${ }^{18}$

Published data on the prevalence of GW from Central and Eastern European countries is limited. Very low lifetime prevalence of self-reported GWs among sexually experienced 1849 -year-old women $(0.4 \%)$ and men $(0.3 \%)$ in Slovenia has been reported. ${ }^{19}$

There are likely many factors that account for the lower lifetime prevalence of GW observed in this study in Baltic countries compared with Western European countries. GW is caused by $\mathrm{HPV}$, which is almost exclusively transmitted by sexual intercourse, and therefore the lower prevalence of GW in Estonia, Latvia and Lithuania could be explained by differences in sexual behaviour. The median lifetime number of sexual partners reported by women in the Baltic countries was three, compared with the five reported by women in Nordic countries. Age at first sexual intercourse in women was also higher in the Baltic 
countries (18 years of age) compared with Nordic countries $(16 \text { years })^{11}$; $43 \%$ of men in Denmark reported having had sexual intercourse with 10 or more female partners during their lifetime, ${ }^{17}$ compared with $28 \%$ of men in the Baltic studies (data not shown). Health surveys conducted in representative samples of the general populations of Baltic countries have shown a lower lifetime number of sexual partners compared with Western European countries. ${ }^{20}$ For example, in the UK the British National Survey of Sexual Attitudes and lifestyles (NATSAL) study, ${ }^{21}$ about $30 \%$ of women and $40 \%$ of men aged 25-44 years reported 10 or more sexual partners in their lifetime. In a similar study from Estonia, the proportion of women reporting over 10 sexual partners was slightly over $10 \%,{ }^{20}$ which fits well with our results of $11.2 \%$.

The observed lower reported prevalence of GW in Baltic countries compared with Western European countries (similar to the lower rates observed in a separate study in Slovenia ${ }^{19}$ ) could also reflect differences in public awareness and/or the specialty of the physicians making the diagnosis, as well as differences in healthcare systems (access to STI/genital health services). ${ }^{6}$

Few studies of HPV seroprevalence in Central/Eastern European countries with low GW occurrence ${ }^{22}{ }^{23}$ have documented HPV6 and HPV11 seroprevalence that are comparable with studies from Western European countries. ${ }^{24} 25$ Unfortunately we were unable to find any HPV6 or HPV11 seroprevalence studies from the three Baltic countries.

Furthermore, last 12 months prevalence of $\mathrm{GW}$ in the Baltic countries was reported most often by women and men aged 30-34 years. In a study from four Nordic countries, GW diagnosed within the previous 12 months were most frequently reported by women aged up to 25 years. ${ }^{11}$ In men in the three Baltic countries, the 12 month prevalence of clinically diagnosed GW increases markedly between the ages of 20 years and 24 years and remains high in those aged 35-39 years. In comparison, among men in Denmark, the 12-month GW prevalence is highest among young men (aged 21-24 years) but decreases thereafter and is very low in men aged 35 years and over. ${ }^{17}$ According to the limited information available on HPV prevalence in the Baltic countries, the highest prevalence of low-risk HPV types are found among women under 25 years of $\mathrm{age}^{8}$-an observation that mirrors similar studies from Western European countries. ${ }^{26} 27$

The factors associated with the prevalence of GW observed in our study are in line with those from other studies. GW is related to high-risk sexual behaviour (history of a STI other than GW or high lifetime number of sexual partners). Traditionally lower income and educational levels have been associated with increased risks for contracting STIs. ${ }^{28}$ The higher prevalence of GW among men coping or living comfortably within their household income might be related to the capacity to recognise GW as a health problem, and the ability and willingness of this group to seek treatment.

Our study has limitations. We used self-reported history of GW as a basis for prevalence estimations. Self-reported measures have been questioned as a reliable source for assessing occurrence. We acknowledge this limitation, yet self-reporting on GW has been used in several studies across Western Europe ${ }^{11} 16$ and the USA, ${ }^{18}$ and we believe that for comparison purposes our results are still valid and of importance. To assure higher specificity we based our prevalence measure on clinically diagnosed episodes of GW. Intuitively, this may imply that the estimated occurrence is most likely an underestimate. Other potential sources of bias associated with the sensitive behaviours and outcomes under investigation are socially desirable responses and recall bias. Further, our results might be influenced by the modest participation rate. Usually the lower the participation rate the higher the STI prevalence (eg, chlamydia) reported from the study ${ }^{29}$ and study participants are more likely to have a STI-related diagnosis/healthcare visit than non-participants. ${ }^{8}$ In the analysis of factors associated with $\mathrm{GW}$, rather robust measures of behavioural and health indicators were used (smoking, hormonal contraceptive use). We used a self-administered survey format with the aim of maximising participation rate and sample size(s), but we recognise that this limited the use of detailed and multifaceted exposure measures. Different sampling methodologies were used in participating countries to accrue a population-based sample (stratified random sampling in Estonia; multistage stratified area probability in Latvia and Lithuania). It is hard to interpret how this might have influenced the study results. To minimise non-response bias the prevalence estimates were weighted to ensure representativeness of the source population. Last but not the least, the cross-sectional study design does not allow us to meaningfully answer the question of whether the lower observed prevalence of GW in Baltic countries (than in Western European countries (developed countries)) is an accurate description of the disease level in the population, or an attribute of the study design and/or awareness and diagnosis of the disease in the population. Use of a strict definition (of clinically diagnosed GW) rather than self-reported 'genital lumps and bumps' could mean that undiagnosed cases of GW were missed, and therefore the true prevalence of $\mathrm{GW}$ may have been higher. However, we believe self-reporting of genital 'lumps and bumps' is not specific for GW given the frequent occurrence of 'lumps and bumps' that may wrongly be identified by patients as GW but, in fact, are normal anatomical structures (eg, pearly penile papules, parafrenular glands, Fordyce spots, vestibular papillae) or other conditions, including infectious diseases (such as molluscum).

The strengths of this study include being the only study to date on the prevalence of GW in the Baltic countries (ie, countries in Europe with a high cervical cancer incidence and mortality). It also has the advantage of being nationwide and based on a random probability sample of participants from the general population.

Our study contributes to the knowledge base of the epidemiology of HPV disease in the population in different regions. Better understanding of the variations and trends in genital HPV disease by the different regions of the world can provide important clues to aetiology and prevention efforts. Further, such data can be useful for public health decision making by providing a baseline for prevaccination status and a basis for assessing the potential burden of genital HPV that can be prevented by vaccination programmes.

\section{Key messages}

- The prevalence of self-reported genital wart diagnosis in Baltic countries was lower than those reported from comparable studies from Western European countries.

- This difference may reflect regional differences in sexual behaviour.

- The difference may also reflect differences in public awareness and/or the specialty of physicians making the diagnosis, as well as differences in healthcare systems. 
Handling editor Jackie A Cassell

Acknowledgements The authors thank Iveta Pudule, the head of the Latvian Public Health Association for her consultancy in data collection in Latvia.

Contributors AU, RR and MN designed the study and RR, AK, DR, ZL and ZP organised and secured the data collection, data entry. AU and RR planned the analysis; RR organised the data for analysis and conducted the statistical analysis. AU wrote the first draft of the manuscript. All authors contributed to revising the manuscript and have approved the final manuscript.

Funding This study was funded by the Investigator initiated programme MISP \#38078 from Merck. MN has received, through the affiliating institute, a research grant from MSD Norway.

\section{Competing interests None}

Patient consent Obtained.

Ethics approval The necessary ethical approval was secured prior to the initiation of the studies in each country (Estonia: Research Ethics Committee of the University of Tartu; Latvia: Central Medical Ethics Committee of Latvia (under the Ministry of Health); Lithuania: Kaunas Regional Biomedical Research Ethics Committee 201205-14, 2013-01-07).

Provenance and peer review Not commissioned; externally peer reviewed.

\section{REFERENCES}

1 Patel $H$, Wagner $M$, Singhal $P$, et al. Systematic review of the incidence and prevalence of genital warts. BMC Infect Dis 2013;13:39.

2 Lacey CJ, Lowndes CM, Shah KV. Chapter 4: Burden and management of non-cancerous HPV-related conditions: HPV-6/11 disease. Vaccine 2006; 24(Suppl 3):S3/35-41.

3 Munoz N, Kjaer SK, Sigurdsson K, et al. Impact of human papillomavirus (HPV)-6/ $11 / 16 / 18$ vaccine on all HPV-associated genital diseases in young women. J Natl Cancer Inst 2010;102:325-39.

4 Donovan B, Franklin N, Guy R, et al. Quadrivalent human papillomavirus vaccination and trends in genital warts in Australia: analysis of national sentinel surveillance data. Lancet Infect Dis 2011;11:39-44.

5 Leval A, Herweijer E, Ploner A, et al. Quadrivalent human papillomavirus vaccine effectiveness: a Swedish national cohort study. I Natl Cancer Inst 2013;105:469-74.

6 Mozalevskis A, Freimane A, Upmace I, et al. Eiropas interneta pētijums par viriešiem,kuriem ir dzimumattiecỉbas ar viriešiem (EMIS), Pētijuma rezultāti. Latvija Riga 2013:36.

7 Pärna K, Rahu K, Helakorpi S, et al. Alcohol consumption in Estonia and Finland: Finbalt survey 1994-2006. BMC Public Health 2010;10:261.

8 Uusküla A, Kals M, McNutt L-A. Assessing non-response to a mailed health survey including self-collection of biological material. Eur J Public Health 2011;21:538-42.

9 Miškinis K, Riklikienè 0 , Kalèdienè $R$, et al. Lietuvos gyventojų informuotumas ir pasitikëjimas privalomojo sveikatos draudimo sistema. Sveikatos Mokslai 2011;21:48-61.

10 Prattala R, Paalanen L, Grinberga D, et al. Gender differences in the consumption of meat, fruit and vegetables are similar in Finland and the Baltic countries. Eur $\rfloor$ Public Health 2007;17:520-5.
11 Kjaer SK, Tran TN, Sparen P, et al. The burden of genital warts: a study of nearly 70,000 women from the general female population in the 4 Nordic countries. $J$ Infect Dis 2007;196:1447-54.

12 Amon J, Brown T, Hogle J, et al. Behavioural Surveillance Surveys. BSS Guidelines for repeated behavioural surveys in populations at risk of HIV: Family Health International. 2000.

13 Bhopal R, Vettini A, Hunt S, et al. Review of prevalence data in, and evaluation of methods for cross cultural adaptation of, UK surveys on tobacco and alcohol in ethnic minority groups. BMJ 2004;328:5.

14 AAPOR. Standard definitions: final dispositions of case codes and outcome rates for surveys. 7th edn. The American Association for Public Opinion Research, 2011.

15 Winship C, Radbill L. Sampling weights and regression analysis. Sociol Methods Res 1994;23:230-57.

16 Fenton KA, Korovessis C, Johnson AM, et al. Sexual behaviour in Britain: reported sexually transmitted infections and prevalent genital Chlamydia trachomatis infection. Lancet 2001;358:1851-4.

17 Munk C, Nielsen A, Liaw KL, et al. Genital warts in men: a large population-based cross-sectional survey of Danish men. Sex Transm Infect 2012;88:640-4.

18 Dinh TH, Sternberg M, Dunne EF, et al. Genital warts among 18- to 59-year-olds in the United States, national health and nutrition examination survey, 1999-2004. Sex Transm Dis 2008:35:357-60.

19 Klavs I, Grgic-Vitek M. The burden of genital warts in Slovenia: results from a national probability sample survey. Euro Surveill 2008;13:19032.

20 Part K, Laanpere M, Rahu K, et al. Estonian women's health: sexual and reproductive health, health behavior, attitudes and use of health care services Survey report. Tartu 2007.

21 Mercer CH, Tanton C, Prah DP, et al. Changes in sexual attitudes and lifestyles in Britain through the life course and over time: findings from the National Surveys of Sexual Attitudes and Lifestyles (Natsal). Lancet 2013;382:1781-94.

22 Fait T, Dvorak V, Skrivanek A, et al. [Epidemiology of genital warts in female population of Czech Republic]. Ceska Gynekol 2012;77:360-3.

23 Hamsikova E, Ludvikova V, Stasikova J, et al. Cross-sectional study on the prevalence of HPV antibodies in the general population of the Czech Republic. Sex Transm Infect 2013;89:133-7.

24 Desai S, Chapman R, Jit M, et al. Prevalence of human papillomavirus antibodies in males and females in England. Sex Transm Dis 2011;38:622-9.

25 Skjeldestad FE, Mehta V, Sings HL, et al. Seroprevalence and genital DNA prevalence of HPV types 6, 11, 16 and 18 in a cohort of young Norwegian women: study design and cohort characteristics. Acta Obstet Gynecol Scand 2008;87:81-8.

26 Sargent A, Bailey A, Almonte M, et al. Prevalence of type-specific HPV infection by age and grade of cervical cytology: data from the ARTISTIC trial. Br I Cancer 2008;98:1704-9.

27 Kjaer SK, Breugelmans G, Munk C, et al. Population-based prevalence, type- and age-specific distribution of HPV in women before introduction of an HPV-vaccination program in Denmark. Int I Cancer 2008;123:1864-70.

28 Harling G, Subramanian S, Barnighausen T, et al. Socioeconomic disparities in sexually transmitted infections among young adults in the United States: examining the interaction between income and race/ethnicity. Sex Transm Dis 2013;40:575-81.

29 Low N, Forster M, Taylor SN, et al. Repeat chlamydia screening among adolescents: cohort study in a school-based programme in New Orleans. Sex Transm Infect 2013;89:20-4. 